\title{
ANALISIS PENGENDALIAN KUALITAS PRODUK (STUDI KASUS : PABRIK TAHU ALAMI LUBUK BUAYA KOTA PADANG)
}

\author{
Usmiar, Leli Suwita \\ Universitas Muhammadiyah Sumatera Barat \\ lelisuwita@gmail.com, usmiar@umsb.ac.id
}

\begin{abstract}
The purpose of this study was to analyze the production quality control process, (1) To identify and analyze the quality control process of the input in each production process of the Lubuk Buaya natural tofu company.

(2) To determine and analyze the level of achievement of product quality standards in each production process of the Lubuk Buaya natural tofu company.

(3) To determine and analyze the level of production damage in each production process of the Lubuk Buaya Natural Tofu company.

This research method is carried out qualitatively with the SQC (Statistical Quality Control) approach, namely by checking sheets, control chart histograms and Pareto diagrams. Data collection techniques are carried out by means of interviews, observation, documentation.

The results of data analysis and discussion show that the production process is in a state of control limits or does not experience deviations. Based on the histogram diagram, it can be concluded that the types of defects that occur in the Lubuk Buaya Natural Tofu Factory in Padang City are pieces with the number of damage is 59 pieces or $55.140 \%$ and the types of damage that are destroyed with the number of damage are 48 pieces or $44.859 \%$. The level of damage is within control limits. From the results of this $S Q C$, it can be seen that product quality control in the selection of raw materials, maintenance of machines and training for workforce so that products get the Indonesian National Standard (SNI)
\end{abstract}

Keywords: Production Process, SQC (Quality Control Standards)

Abstrak : Tujuan penelitian ini untuk menganalisis proses pengendalian kualitas produksi, (1) Untuk mengetahui dan menganalisis proses pengendalian kualitas input pada setiap proses produksi perusahaan tahu alami Lubuk Buaya.

(2) Untuk mengetahui dan menganalisis tingkat ketercapaian standar kualitas produk pada setiap proses produksi perusahaan tahu alami Lubuk Buaya.

(3) Untuk mengetahui dan menganalisis tingkat kerusakan produksi pada setiap proses produksi perusahaan Tahu Alami Lubuk Buaya.

Metode penelitian ini dilakukan secara kualitatif dengan pendekatan SQC (Statistik Quality Control) yaitu dengan lembar pengecekan, histogram peta kendali dan diagram pareto. Teknik pengumpulan data yang dilakukan dengan cara wawancara, observasi, dokumentasi.

Hasil analisis data dan pembahasan menunjukan bahwa proses produksi dalam keadaan batas kendali atau tidak mengalami penyimpangan. Berdasarkan diagram histogram dapat disimpulkan jenis kecacatan yang terjadi pada Pabrik Tahu Alami Lubuk Buaya Kota Padang adalah kepotong dengan jumlah kerusakan 59 potong atau 55,140\% dan jenis kerusakan hancur dengan jumlah kerusakan 48 potong atau $44,859 \%$. Tingkat keruskan dalam batas kendali. Dari hasil SQC ini dapat mengetahui pengedalian kualitas produk dalam pemilihan bahan baku, pemeliharan mesin dan pelatihan untuk ketenagaan kerja agar produk mendapatkan Standar Nasional Indonesia (SNI)

Kata Kunci : Proses Produksi, SQC (Standar Quality Control)

\section{A. PENDAHULUAN}

\subsection{Latar Belakang Masalah}

Setiap perusahaan, baik yang bergerak dibidang produksi barang maupun jasa, mempunyai tujuan yang sama, yaitu untuk mendapat keuntungan, supaya perusahaan tetap 
bertahan dan berkembang. Hal ini dapat dilakukan, jika perusahaan dapat mempertahankan dan meningkatkan penjualan.

Perusahaan dapat bertahan dan berkembang di pasar, bila perusahaan dapat mempertahankan kualitas produk, makanya perusahaan perlu mengadakan pengendalian terhadap kualitas produk. Dalam hal ini, perusahaan akan terus menyempurnakan dengan proses monitoring.

Penelitian dilakukan pada perusahaan tahu alami lubuk buaya kota padang, terletak di Koto Tangah Padang. Perusahaan bergerak di bidang pengelolaan tahu. Dimana bahan baku utamanya kacang kedelai yang berasal dari kacang import. Proses pengelolaan kacang kedelai di perusahaan ini berlangsung secara terus menerus dengan cara bekerja secara bergiliran ( shif work) pada karyawan.

Perusahaan tahu alami lubuk buaya, merupakan salah satu industri kecil di kota Padang. perusahaan tahu ini berdiri sejak tahun 1999.Pemilik pabrik tahu ini bernama Ibu Habibah dan Bapak Muakhir. Proses produksi tahu ini dilakukan tepat di belakang rumah Ibu Habibah yang berada di depan jalan raya berseberangan dengan Pasar Lubuk Buaya Padang.

Tahu merupakan makanan tradisional yang terbuat dari kedelai yang kaya akan protein, dan rendah sodium, kolestrol dan kalori. Makanan ini telah memiliki sejarah sehinnga 2000 tahun lamanya. Karena efek kedelai baik untuk kesehatan, tahu dianggap sebagai manakan sehat, jika dikonsumsi bisa bermanfaat bagi kesehatan.

Pengendalian kualitas (Quality Control) sangat penting, karena dapat menentukan berhasil atau tidaknya perusahaan dalam mecapai tujuan. Kegiatan pengendalian kualitas (Quality Control) yang kurang efektif secara terus menerus dapat mengakibatkan bayaknya produksi yang rusak atau cacat, target produksi tidak tercapai, baik dari segi kualitas maupun kuantitas.

Tantangan untuk meningkatkan pengendalian kualitas produk, sehingga produk sesuai dengan standar mutu yang dihadapi oleh perusahaan Tahu Alami Lubuk Buaya Padang.

Dengan memperhatikan hal tersebut, peneliti tertarik mengangkut judul penelitian yang akan dilakukan di perusahaan Tahu Alami Lubuk Buaya dengan judul " Analisis Pengendalian Kualitas Produk (Studi Kasus : Pabrik Tahu Alami Lubuk Buaya Kota Padang )

\subsection{Rumusan Masalah}

Berdasarkan latar belakang masalah dapat disimpulkan rumusan masalah sebagai berikut :

1. Bagaimana proses pengendalian kualitas input dilakukan oleh perusahaan Tahu Alami Lubuk Buaya?

2. Bagaimanakah tingkat ketercapaian standar kualitas produk pada setiap proses produksi perusahaan Tahu Alami Lubuk Buaya?

3. Bagaimanakah tingkat kerusakan produksi pada setiap proses produksi perusahaan Tahu Alami Lubuk Buaya?

\subsection{Tujuan Penelitian}

1. Untuk mengetahui dan menganalisis proses pengendalian kualitas inputpada setiap proses produksi perusahaan Tahu Alami Lubuk Buaya.

2. Untuk mengetahui dan menganalisis tingkat ketercapaian standar kualitas produk pada setiap proses produksi perusahaan Tahu Alami Lubuk Buaya.

3. Untuk mengetahui dan menganalisis tingkat kerusakan produksi pada setiap proses produksi perusahaan Tahu Alami Lubuk Buaya.

\section{B. Tinjauan Pustaka}

\subsection{Pengendalian Kualitas}

Pengendalian Kualitas adalah kegiatan untuk memastikan apakahkebijaksanaan dalam hal kualitas dapat tercermin dalam hasil akhir. Dalam perkataan lain pengawasan kualitas merupakan usaha untuk mempertahankan kualitas dari barang yang dihasilkan, agar sesuai 
dengan spesifikasi produk yang telah ditetapkan berdasarkan kebijakan pimpinan perusahaan. menurut Assauri (2008:299)

\subsection{Menetapkan Sasaran Produk}

Produk merupakan segala sesuatu yang dapat ditawarkan produsen untuk diperhatikan , diminta, dicari, dibeli, digunakan atau dikonsumsi sebagai pemenuhan kebutuhan atau keinginan pasar yang bersangkutan. Produk yang ditawarkan tersebut meliputi barang, jasa, orang atau tempat, organisasi , dan ide. (Tjiptono ,2008: 88)

\subsection{Proses Produksi}

Proses adalah suatu cara, metode maupun teknik untuk penyelenggaraan atau pelaksanaan dari suatu hal tertentu" (Ahyari, 2002: 65). Sedangkan produksi adalah: "Kegiatan untuk mengetahui penambahan manfaat atau penciptaan faedah, bentuk, waktu dan tempat atas faktor-faktor produksi yang bermanfaat bagi pemenuhan konsumen " (Reksohadiprodjo, 2000: $1)$.

Proses produksi merupakan rangkaian kegiatan yang dengan menggunakan peralatan, sehingga masukan atau input dapat diolah menjadi keluaran yang berupa barang atau jasa yang akhirnya dapat dijual kepada pelanggan untuk memungkinkan perusahaan memperoleh hasil keuntungan yang diharapkan (Assauri 2008 : 35). Proses produksi yang dilakukan terkait dalam suatu sistem, sehingga pengolahan atau pentransformasian dapat dilakukan dengan menggunakan peralatan yang dimiliki.

\subsection{Produk Akhir}

Produk akhir yang yang dihasilkan adalah produk sesuai sasaran kualitas yang ditetapkan. Produk berkualitas adalah "Suatu kondisi fisik, sifat, dan kegunaan suatu barang yang dapat memberikan kepuasan konsumen secara fisik maupun psikologis, sesuai dengan nilai uangyang dikeluarkan."Kualitas diperlukan oleh setiap perusahaan yang mengolah bahan baku menjadisebuah produk yang nantinya dapat memenuhi kebutuhan konsumen (Prawirosentono 2007: 320)

\subsection{Produk cacat}

Produk cacat adalah produk yang dihasilkan dalam proses produksi, dimana produk yang dihasilkan tersebut tidak sesuai dengan standar mutu yang ditetapkan, tetapi masih bisa diperbaiki dengan mengeluarkan biaya tertentu (Bustami, 2007:136)

\section{METODE PENELITIAN}

\subsection{Populasi dan Sampel}

\subsection{Teknik Analisis Data}

Untuk menjawab tujuan penelitian dan hipotesis digunakan teknik analisis, SQC Statistic Quality Control sebagai berikut:

\section{Analisis Statistical Quality Control}

Dalam penyelesaian permasalahan pengendalian kualitas dengan mengunakan metodeSQC (statistical quality control) adapun langkah langkah sebagai berikut :

1. Lembar pengecekan

Sebuah lembar pengecekan (check sheet) adalah suatu formulir yang dirancang untuk mecatat data. Dalam banyak kasus pecacatan dilakukan sehingga saat data diambil, polanya dapat dilihat dengan mudah . lembar periksa membantu analisis menentukan fakta atau pola yang mungkin dapat membantu analisis selanjutnya.(heizer 2009:316)

2. Diagram Batang (Histogram)

Histogram merupakan salah satu alat yang membantu untuk menemukan variasi.Histogram menunjukkan cakupan nilai sebuah perhitungan danfrekuensi dari setiap nilai yang muncul. Histogram dapat dipergunakan sebagai suatu alat untuk mengkomunikasikan informasi tentang variasi dalam proses dan membantu manajemen dalam membuat keputusan-keputusan yang berfokus pada usaha perbaikan yang dilakukan secara kontinu atau terus-menerus (Heizer, 2009:322).

Untuk memudahkan analisis, kelompokan terlebih dahulu data yang sekelas,biasanya dilihat secara kelompok dan kelompok-kelompok dari data tersebutakan bertebaran mulai dari 
kelas rendah sampai yang tinggi, namun apabiladata yang ada bersifat kualitatif, pengelompokannya dapat dilakukan secarabebas seperti terlihat pada contoh histogram sederhana di bawah ini (Besterfield, 2009:89).

3. Analisis Diagram Kontrol (P-Chart)

Peta kendali adalah reprsentasi grafik data dari data sejalan dengan waktu yang menunjukan batas atas dan bawah proses yang ingin kita kendaliakan . diagram kendali dibuat sedemikian rupa sehingga data baru dapat dibandingkan dengan data lampu dengan cepat . sampel output proses diambil dan rata rata sampel ini dipetakan pada sebuah diagram yang memiliki batas batas nya. Batas atas dan batas bawah dalam sebuah diagram kendali dapat dinyatakan dalam satuan temperatur, tekanan, berat, panjang dan sebagainya

Menunjukan pemetaan persentase sebuah sampel kedalam sebuah diagram kendali. Saat rata rata sampel jatuh diantara batas kendali atas dan batas kendali bawah, serta tidak dapat pola tertentu yang dapat dilihat, proses nya dikatakan berada dalam kendali atau tidak sesuai (heizer 2009:322)

Peta kendali dgunakan untuk membantu mendeteksi adanya penyimpangan dengan cara menetapkan batas batas kendali:

Apapun langkah langkah membuat peta kendali p sebagai berikut :

A. Menghitung persentase kerusakan

$$
\mathrm{P}=\underline{\mathrm{np}}
$$

$$
\mathrm{n}
$$

keterangan :

$\mathrm{np}:$ Jumlah gagal dalam sub grup

$\mathrm{n}$ : jumlah produksi realisasi

sub grup : hari ke-

B. Menghitung Garis Tengah

Central line / garis pusat atau garis tengah (CL), merupakan garis yang melambangkan tidak adanya penyimpangan dari krateristik sampel.

$$
\begin{aligned}
& \mathrm{CL}=\dot{\mathrm{p}} \frac{\sum n p}{\sum n} \\
& \text { Keterangan : } \\
& \dot{\mathrm{p}}=\text { rata rata kerusakan produk } \\
& \sum n p=\text { jumlah total rusak } \\
& \sum n=\text { jumlah total produksi realisasi }
\end{aligned}
$$

C. Cara Menghitung Batas Kendali Atas(UCL)

Upper Control Limit/ Batas Kendali Atas (UCL) merupakan garis batas untuk suatu untuk penyimpangan yang masih diijin kan

$$
\mathrm{UCL}=\dot{\mathrm{p}}+3 \frac{\sqrt{\dot{\mathrm{p}}(1-\dot{\mathrm{p}})}}{n}
$$

Keterangan :

$\dot{p}=$ rata rata kerusakan produk

$\mathrm{n}=$ jumlah produksi

D. Cara Menghitung Batas Kendali Bawah

Lower Control Limit / Batas Kendali Bawah (LCL) merupakan garis bahwa untuk suatu penyimpangan dari karakteristik sampel

$$
\mathrm{LCL}=\dot{\mathrm{p}}-3 \frac{\sqrt{\hat{\mathrm{p}}(1-\dot{\mathrm{p}})}}{n}
$$

Keterangan :

$\dot{\mathrm{p}}=$ rata rata kerusakan produk

$$
\mathrm{n}=\text { jumlah produksi }
$$

sumber (heizer render 2006:322) 


\section{PEMBAHASAN}

\subsection{Analisis Statistical Quality Control}

Dalam penyelesaian permasalahan pengendalian kualitas dengan mengunakan metode SQC (statistical quality control) adapun langkah langkah sebagai berikut :

1. Lembar pengecekan

Sebuah lembar pengecekan (check sheet) adalah suatu formulir yang dirancang untuk mecatat data. Dalam banyak kasus pecacatan dilakukan sehingga saat data diambil, polanya dapat dilihat dengan mudah .lembar periksa membantu analisis menentukan fakta atau pola yang mungkin dapat membantu analisis selanjutnya.(heizer render 2009:316)

2. Histogram

Histogram menunjukan cakupan nilai sebuah perhitungan dan frekuensi dari setiap nilai yang muncul. Histogram menunjukan peristiwa yang paling sering terjadi dan juga variasi dalam pengukuran. Statistic deskriptif. Seperti rata rata dan standar devisiasi dapat dihitung untuk menjelaskan ditribusinya. Walaupun demikian, datanya harus selalu dipetakan sehingga distribusinya dapat "terlihat" sebuah gambaran visual dari distribusi juga dapat memberikan informasi mengenai penyebab variasinya. (Heizer 2009: 322)

Apapun langkah langkah membuat peta kendali p sebagai berikut :

Menghitung Persentase Kerusakan

$$
\mathrm{P}=\frac{\mathrm{np}}{\mathrm{n}}
$$

keterangan :

$\mathrm{np} \quad$ : Jumlah gagal dalam sub grup

$\mathrm{n} \quad$ : jumlah produksi realisasi

sub grup : hari ke-

makanya menghitung data nya adalah sebagai berikut :

$$
\text { sub grup } 1=\mathrm{p}=\frac{\mathrm{np}}{\mathrm{n}}=\frac{14}{500}=0,028
$$

$\operatorname{sub}$ grup $2=\mathrm{p}=\underline{\mathrm{np}}=\underline{18}=0,0375$

$$
\text { n } 480
$$

sub grup $3=p=\underline{n p}=\underline{13}=0,0265$

$$
\text { n } 490
$$

$\operatorname{sub}$ grup $4=p=\underline{n p}=\underline{7}=0,014$

$$
\mathrm{n} \quad 500
$$

sub grup $5=\mathrm{p}=\underline{\mathrm{np}}=\underline{11}=0,022$

$$
\text { n } 500
$$

sub grup $6=p=\underline{n p}=\underline{11}=0,0224$

$$
\text { n } 490
$$

sub grup $7=p=\underline{n p}=\underline{12}=0,0255$

$$
\text { n } 470
$$

sub grup $8=\mathrm{p}=\underline{\mathrm{n} p}=\underline{6}=0,012$

$$
\mathrm{n} 500
$$

sub grup $9=\mathrm{p}=\underline{\mathrm{np}}=\underline{7}=0,014$

$$
\mathrm{n} \quad 500
$$

sub grup $10=\mathrm{p}=\underline{\mathrm{np}}=\underline{8}=0,016$

$$
\text { n } 500
$$


Table 4.1

Perhitungan Persentase Kerusakan Produk

\begin{tabular}{|c|c|c|c|c|c|c|c|}
\hline \multicolumn{6}{|c|}{ Output } & \multirow{3}{*}{$\begin{array}{c}\text { rata rata } \\
\text { kerusakan } \\
(\dot{p})\end{array}$} & \multirow{3}{*}{$\begin{array}{l}\text { Persent } \\
\text { ase }\end{array}$} \\
\hline \multirow[t]{2}{*}{ No } & \multirow[t]{2}{*}{ Tanggal } & \multirow{2}{*}{$\begin{array}{l}\text { Targe } \\
\text { t } \\
\text { (poton } \\
\text { gan } \\
\text { tahu ) }\end{array}$} & \multirow{2}{*}{$\begin{array}{l}\text { Jumlah } \\
\text { produksi/ } \\
\text { realisasi } \\
\text { (potongan } \\
\text { tahu) }\end{array}$} & \multicolumn{2}{|c|}{ Jenis kerusakan } & & \\
\hline & & & & $\begin{array}{l}\text { kepot } \\
\text { ong }\end{array}$ & Hancur & & \\
\hline 1 & $\begin{array}{l}07 / 09 / 2 \\
020\end{array}$ & 500 & 500 & 10 & 4 & 7 & $2,8 \%$ \\
\hline 2 & $\begin{array}{l}08 / 09 / 2 \\
020\end{array}$ & 500 & 480 & 8 & 10 & 9 & $3,37 \%$ \\
\hline 3 & $\begin{array}{l}09 / 09 / 2 \\
020\end{array}$ & 500 & 490 & 5 & 8 & 6,5 & $2,65 \%$ \\
\hline 4 & $\begin{array}{l}10 / 09 / 2 \\
020\end{array}$ & 500 & 500 & 3 & 4 & 3,5 & $1,4 \%$ \\
\hline 5 & $\begin{array}{l}11 / 09 / 2 \\
020\end{array}$ & 500 & 500 & 5 & 6 & 5,5 & $2,2 \%$ \\
\hline 6 & $\begin{array}{l}12 / 09 / 2 \\
020\end{array}$ & 500 & 490 & 7 & 4 & 5,5 & $2,24 \%$ \\
\hline 7 & $\begin{array}{l}13 / 09 / 2 \\
020\end{array}$ & 500 & 470 & 9 & 3 & 6 & $2,55 \%$ \\
\hline 8 & $\begin{array}{l}14 / 09 / 2 \\
020\end{array}$ & 500 & 500 & 4 & 2 & 3 & $1,2 \%$ \\
\hline 9 & $\begin{array}{l}15 / 09 / 2 \\
020\end{array}$ & 500 & 500 & 5 & 2 & 3,5 & $1,4 \%$ \\
\hline 10 & $\begin{array}{l}16 / 09 / 2 \\
020\end{array}$ & 500 & 500 & 3 & 5 & 4 & $1,6 \%$ \\
\hline Tota & & & 4930 & 59 & 48 & 53,5 & $21,02 \%$ \\
\hline
\end{tabular}

Sumber : data diolahan sendiri

Berdasarkan table 4.1 diatas dalam perhitungan persentase kerusakan produk terdapat persentase kerusakan dilihat dari total dari persentase kerusakan total nya 21,02

Table 4.2

Hasil Perhitungan CL, UCL, LCL

\begin{tabular}{|c|c|c|c|c|c|c|c|c|c|}
\hline \multicolumn{6}{|c|}{ Output } & \multirow{3}{*}{$\begin{array}{l}\text { Perse } \\
\text { ntase }\end{array}$} & \multirow{3}{*}{ CL } & \multirow{3}{*}{ UCL } & \multirow{3}{*}{ LCL } \\
\hline \multirow[t]{2}{*}{ No } & \multirow[t]{2}{*}{ Tanggal } & \multirow{2}{*}{$\begin{array}{l}\text { Target } \\
\text { (potonga } \\
\text { n tahu ) }\end{array}$} & \multirow{2}{*}{$\begin{array}{l}\text { Jumlah } \\
\text { produksi/ } \\
\text { realisasi } \\
\text { (potonga } \\
\text { n tahu) }\end{array}$} & \multicolumn{2}{|c|}{$\begin{array}{c}\text { Jenis } \\
\text { kerusakan }\end{array}$} & & & & \\
\hline & & & & $\begin{array}{c}\text { kepot } \\
\text { ong }\end{array}$ & $\begin{array}{c}\mathrm{Ha} \\
\mathrm{ncu} \\
\mathrm{r}\end{array}$ & & & & \\
\hline 1 & $07 / 09 / 2020$ & 500 & 500 & 10 & 4 & $2,8 \%$ & 1,1394 & 53,8179 & 53,1821 \\
\hline 2 & $08 / 09 / 2020$ & 500 & 480 & 8 & 10 & $3,37 \%$ & 1,1394 & 53,8312 & 53,1688 \\
\hline 3 & $09 / 09 / 2020$ & 500 & 490 & 5 & 8 & $2,65 \%$ & 1,1394 & 53,5244 & 53,1756 \\
\hline 4 & $10 / 09 / 2020$ & 500 & 500 & 3 & 4 & $1,4 \%$ & 1,1394 & 53,8179 & 53,1821 \\
\hline 5 & $11 / 09 / 2020$ & 500 & 500 & 5 & 6 & $2,2 \%$ & 1,1394 & 53,8179 & 53,1821 \\
\hline 6 & $12 / 09 / 2020$ & 500 & 490 & 7 & 4 & $2,24 \%$ & 1,1394 & 53,5244 & 53,1821 \\
\hline 7 & $13 / 09 / 2020$ & 500 & 470 & 9 & 3 & $2,55 \%$ & 1,1394 & 53,8283 & 53,1756 \\
\hline 8 & $14 / 09 / 2020$ & 500 & 500 & 4 & 2 & $1,2 \%$ & 1,1394 & 53,8179 & 53,1821 \\
\hline 9 & $15 / 09 / 2020$ & 500 & 500 & 5 & 2 & $1,4 \%$ & 1,1394 & 53,8179 & 53,1821 \\
\hline 10 & $16 / 09 / 2020$ & 500 & 500 & 3 & 5 & $1,6 \%$ & 1,1394 & 53,8179 & 53,1821 \\
\hline \multicolumn{2}{|c|}{ Total } & & 4930 & 59 & 48 & & & & \\
\hline
\end{tabular}


Sumber : data diolah sendiri

Berdasarkan hasil table 4.5 dari hasil persentase perhitungan nilai persentse dari setiap supgrup, nilai garis tengah (CL), nilai batas atas (UCL), dan nilai batas bawah (LCL) diketahui, maka selanjutnya dapat dibuat peta kendali $\mathrm{p}$ yang dapat dilihat pada gambar berikut ini dari hasil persentase perhitungan nilai persentse dari setiap supgrup, nilai garis tengah (CL), nilai batas atas (UCL), dan nilai batas bawah (LCL) diketahui, maka selanjutnya dapat dibuat peta kendali $p$ yang dapat dilihat pada gambar berikut ini

Gambar 4.1

Grafik Peta Kendali P (P-Chart)

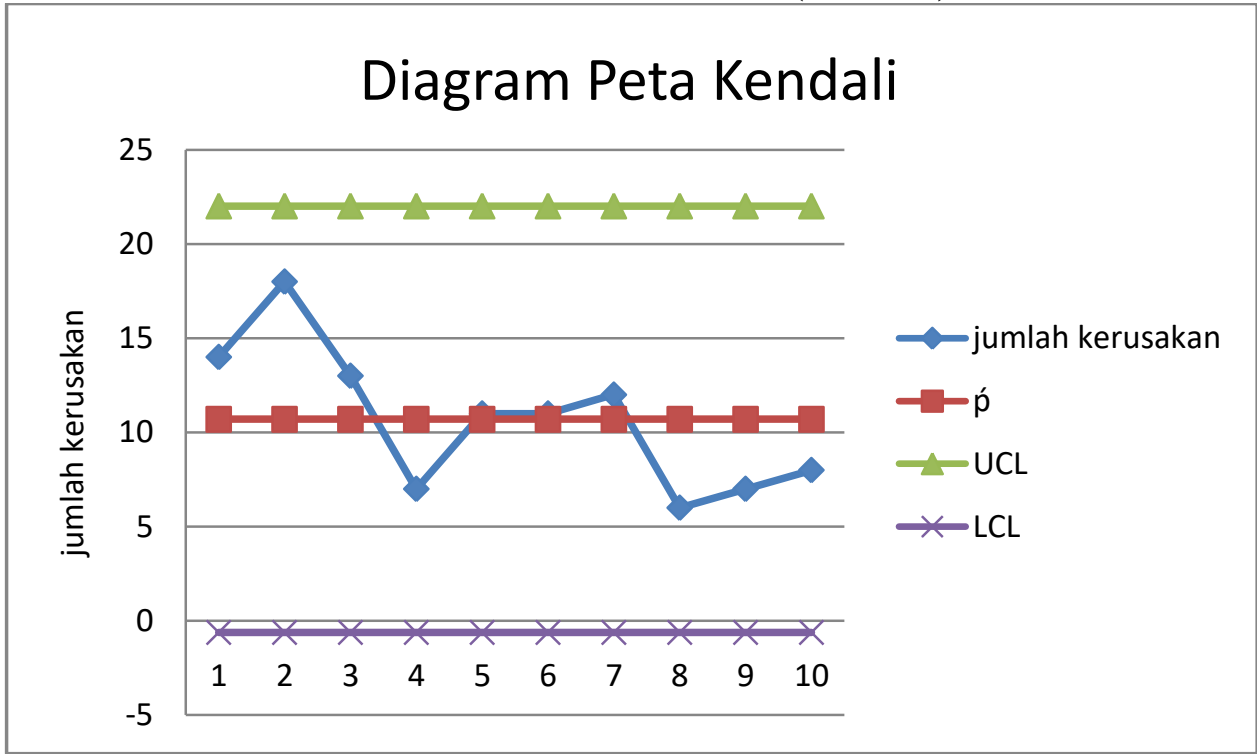

Berdasarkan gambar 4.1 pada peta kendai $\mathrm{p}$ diatas, dapat dilihat bahwa terdapat data masih berada dalam batas kendali karena jumlah kerusakan tidak ada yang melewati batas kendali atas dan batas kendali bawah

Table 4.3

Presentase Kerusakan

\begin{tabular}{|c|c|c|c|c|}
\hline No & Jenis kerusakan & Jumlah keruskan & $\begin{array}{c}\text { Presentase } \\
\text { kerusakan \% }\end{array}$ & $\begin{array}{c}\text { Presentase } \\
\text { kumulatif \% }\end{array}$ \\
\hline 1 & Kepotong & 59 & $55,140 \%$ & $55,140 \%$ \\
\hline 2 & Hancur & 48 & $44,859 \%$ & $100,00 \%$ \\
\hline & total & 107 & $100 \%$ & \\
\hline
\end{tabular}

Sumber : data diolah sendiri

Berdasarkan perhitungan diatas maka dapat digambarkan dalam diagram pareto perbandingan jenis kerusakan yang terjadi sebagai berikut : 
Gambar 4.2

Diagram Pareto Kerusakan Tahu

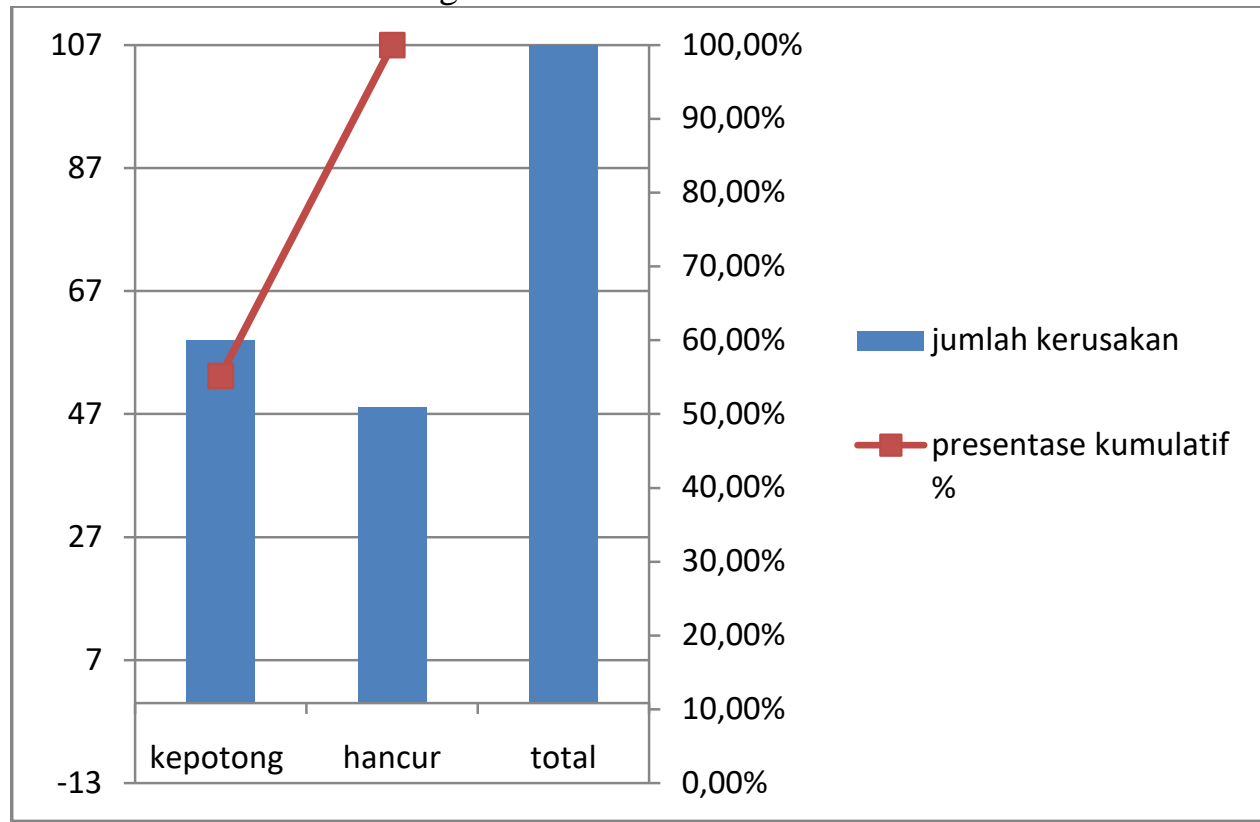

Berdasarkan gambar 4.3 diagram pareto diatas menunjukan jenis kerusakan yang sering terjadi adalah masalah kepotong dengan jumlah kerusakan 59 potong atau 55,140\% dan jenis kerusakan yang hancur jumlah kerusakan 48 potong atau $44,859 \%$.

\section{E. PENUTUP}

\subsection{Kesimpulan}

Berdasarkan penelitian dan pembahasan produk cacat dapat disimpulkan bahwa :

1. Produksi tahu yang dihasil masih berada dalam batas kendali

2. Tingkat ketercapaian standar kualitas dalam setiap proses produksi masih sesuai dengan standar kualitas yang ditetapkan perusahaan

3. Tingkat kerusakan yang menyebabkan terjadinya kerusakan pada produk tahu yaitu tidak ada pemeliharan dalam mesin dan peralatan produksi yang rutin dilakukan, kebersihan ruangan dari asap dan debu serta ketelitian dan kehati hati tenaga kerja dalam bekerja.

\subsection{Saran}

Bagi Pabrik Tahu Alami Lubuk Buaya Padang

1. Pemilik Pabrik Tahu Alami Lubuk Buaya Kota Padang perlu mengadakan pelatihan khusus untuk pengendalian kualitas dari penerimaan bahan baku komponen, proses produksi berlangsung dan produk jadi pada karyawan. Dengan adanya pelatihan tersebut diharapkan agar tenaga kerja dapat lebih teliti dan terampil dalam melaksanakan tugas atau pekerjaan yang dilakukan dapat berjalan sesuai dengan prosedur kerja dari perusahaan.

2. Perlu adanya peningkatan, perawatan mesin, pemilihan bahan baku secara berkala agar standar kualitas perusahaan tetap terjaga.

3. Serta melakukan pergantian pada komponen mesin yang telah rusak, sehingga akan mengefesienkan proses produksi dan mencegah kerusakan mesin. Agar menuruangi tingkat kerusakan pada produksi produk tahu.

\section{F. DAFTAR PUSTAKA}

Ahyari, Agus. 2002. Manajemen Produksi; Pengendalian Produksi, edisi 
empat, buku dua. BPFE.Yogyakarta.

Assauri, Soyjan. 2008. Manajemen Produksi dan Operasi. Jakarta: LPFEUI.

Besterfield, D. H. 2009. Quality Control (8thedition). New Jersey: Pearson

PrenticeHall.

Bustami dan Nurlela , 2007 Akuntansi biaya Yogyakarta, Ghara Ilmu Faiz Al Fahri . 2010, Pengendalian Kualitas Produk Edisi Empat Buku 2 Heizer dan Render. 2009. Manajemen Operasi. Buku 1 Edisi 9. Jakarta :

Salemba

Montgomery, Douglas C. 2001. Introduction to Statistical Quality

Control, 4Edition. John Wiley \& Sons, Inc. New York.

Marshelia Mayang Sari 2013. Manajemen Operasional Buku 1 Edisi 9

Haming dan Nurnajamuddin, Mahfud. 2007. Manajemen Produksi

Modern Operasi Manufaktur dan Jasa. Jakarta: Bumi Aksara.

Herawati .2012, Manajemen Operasi . Buku 1 Edisi 9 Jakarta

Prawirosentono, Suyadi. 2007. Manajemen Operasi . Edisi 4. Jakarta :

Bumi Aksara.

Sukanto reksohadiprodjo, 2000. Dasar Dasar Manajemen . Yogyakarta . BPFE

Sukarjo kadi projo, 2000 Manajemen Operasi . buku 1 Edisi 9 jakarta

Sukardi .2008, Manajemen Operasi Buku 1 Edisi 9 Jakarta

Tjiptono Fandi , 2008. Strategi pemasaran ,Edisi III, Yogyakarta : CV . Andi

Offset

Tisnowati Heny 2008 Dasar Dasar Manajemen Edisi 4 Jakarta

(sumber:https://www.researchgate.net/publication/339023811_Karakteristik_Dan_Analisis_Se nsorik Produk Tahu dengan Koagulan Alam ) i 